\title{
Effects of terroir on the terpene compounds of Muscat of Bornova Native white grape variety grown in Turkey
}

\author{
Zeynep Dilan Celik ${ }^{1}$, Selin Yabacı Karaoğlan ${ }^{3}$, Merve Darıc1², Haşim Kelebek ${ }^{3}$, Burçak İşçi ${ }^{4}$, Ege Kaçar ${ }^{4}$, Ahmet \\ Altındişli ${ }^{4}$, and Turgut Cabaroğlu 2 ,a \\ ${ }^{1}$ Çukurova University, Department of Biotechnology, Adana, Turkey \\ ${ }^{2}$ Çukurova University, Agriculture Faculty, Food Engineering Department, Adana, Turkey \\ ${ }^{3}$ Adana Science and Technology University, Faculty of Engineering and Natural Science, Food Engineering Department, \\ Adana, Turkey \\ ${ }^{4}$ Ege University, Agricultural Faculty, Horticulture Department, İzmir, Turkey
}

\begin{abstract}
Muscat of Bornova is a white and aromatic native grape variety of Vitis vinifera which is largely predominant in the Izmir-Manisa province of the Aegan region. In this study, the effect of three different terroirs (Kemaliye, Halilbeyli, Menderes) located in Izmir-Manisa province and two different years (2013-2014) on the terpene compounds of Muscat of Bornova grapes were investigated. The terpene compounds were extracted by using liquid-liquid extraction method and identified and quantified by GC-MS-FID. In 2013 vintage eighteen terpene compounds were identified and quantified. The concentration of total terpene compounds in Muscat of Bornova grapes from Menderes determined $2.1 \mathrm{mg} / \mathrm{l}$, in Halilbeyli $1.3 \mathrm{mg} / \mathrm{l}$ and in Kemaliye $1.7 \mathrm{mg} / \mathrm{l}$. In 2014 vintage eighteen terpene compounds were identified and quantified. In 2014 a total concentration of terpene compounds decreased in grapes from Menderes and determined $1.8 \mathrm{mg} / \mathrm{L}$, in Halilbeyli the results were the same as the first vintage and found $1.3 \mathrm{mg} / \mathrm{l}$ and in Kemaliye there was an increase with $2.6 \mathrm{mg} / \mathrm{l}$. Among monoterpenes, linalool, $\alpha$-terpineol, citronellol, nerol and geraniol show significant differences between different terroirs.
\end{abstract}

\section{Introduction}

Terroir, is one of the most important factors in viticulture because it affects the organoleptic characteristics of grapes and consequently its wines. The term covers the topography, climate, and soil, which are the whole natural environment of the vine, even cultural practices included [1].

Turkey is the sixth largest grape producing country in the world with the production of 4.2 million tonnes per year. The first traces of viticulture and winemaking in Anatolia date back 7,000 years. Muscat of Bornova is a native aromatic white grape variety (Vitis vinifera) grown in the Aegean region, mainly in the Menderes/Izmir and Kemaliye/Manisa terroirs. This grape variety is used for the production of one of the highest quality aromatic white wines in Turkey. Muscat of Bornova variety is characterized by a high intensity of floral descriptors, monoterpens being responsible for this floral notes [2]. The typical flavor of Muscat wines is mainly due to volatile compounds coming from grapes, which are mainly various volatile monoterpene compounds [3-5].

The effects of altitude [6], water availability [7], slope [8] and exposure [9] on vine have been evaluated for some important cultivars. However, the influence of the environmental factors on grapes' characteristics of Muscat of Bornova, grown in Turkey has not been studied, yet. The present research analyses the general composition and terpene compounds on Muscat of Bornova variety grown in

${ }^{a}$ Corresponding author: tcabar@cu.edu.tr the Menderes/Izmir, Halilbeyli and Kemaliye/Manisa, to determinate the influence of terroir.

\section{Materials and methods}

\subsection{Grape samples and vineyards}

This study was carried out over two seasons (2013-2014) and in three regions. Healthy grapes of cv. Muscat of Bornova were manually harvested from commercial vineyards in Menderes, Halilbeyli and Kemaliye terroirs (Fig. 1) and transported to University of Cukurova, Food Engineering Department, for the analyses. Menderes is close to the Aegean sea with the coordinates, latitude (North) $38^{\circ} 15^{\prime} 11^{\prime \prime}$ and longitude (East) $27^{\circ} 10^{\prime} 60^{\prime \prime}$, its altitude is $90 \mathrm{~m}$. The soil type of this terroir is "sandy-loamy soil" in general. The climate is mild. Halilbeyli is located in inner Izmir, close to Manisa, its coordinates, latitude (North) $38^{\circ} 28^{\prime} 56^{\prime \prime}$ and longitude (East) $27^{\circ} 38^{\prime} 20^{\prime \prime}$, the altitude is $115 \mathrm{~m}$. The soil type of Halilbeyli is also sandyloamy soil. Kemaliye is in a climate transition area which shows continental climate features, its coordinates, latitude (North) 38 28'36" and longitude (East) $28^{\circ} 24^{\prime} 33^{\prime \prime}$, the altitude is $245 \mathrm{~m}$. Soil is mostly "sandy-loamy" (Table 1).

\subsection{Meteorological parameters}

The meteorological data $\left(T_{\max }, T_{\min }, T_{\text {avg }}, T_{\max }-T_{\min }\right.$, RHavg, Rainfall) were provided by the Meteorological weather stations placed in Izmir and Manisa (Table 1). 
Table 1. Meteorological parameters of studied terroirs.

\begin{tabular}{|c|c|c|c|c|c|c|c|c|c|}
\hline & \multicolumn{3}{|c|}{ Menderes } & \multicolumn{3}{|c|}{ Halilbeyli } & \multicolumn{3}{|c|}{ Kemaliye } \\
\hline & $\begin{array}{l}\text { Long time } \\
\text { period }\end{array}$ & 2013 & 2014 & $\begin{array}{c}\text { Long time } \\
\text { period }\end{array}$ & 2013 & 2014 & $\begin{array}{c}\text { Long time } \\
\text { period }\end{array}$ & 201 & 2014 \\
\hline \multirow{2}{*}{ Coordinates } & \multicolumn{3}{|c|}{$38^{\circ} 15^{\prime} 11^{\prime \prime} \mathrm{N}$} & \multicolumn{3}{|c|}{$38^{\circ} 28^{\prime} 56^{\prime \prime} \mathrm{N}$} & \multicolumn{3}{|c|}{$38^{\circ} 28^{\prime} 36^{\prime \prime} \mathrm{N}$} \\
\hline & \multicolumn{3}{|c|}{$27^{\circ} 10^{\prime} 60^{\prime \prime} \mathrm{E}$} & \multicolumn{3}{|c|}{$27^{\circ} 38^{\prime} 20^{\prime \prime} \mathrm{E}$} & \multicolumn{3}{|c|}{$28^{\circ} 24^{\prime} 33^{\prime \prime} \mathrm{E}$} \\
\hline Altitude (m) & \multicolumn{3}{|c|}{90} & \multicolumn{3}{|c|}{115} & \multicolumn{3}{|c|}{245} \\
\hline$T_{\max }\left({ }^{\circ} \mathrm{C}\right)$ & $32.1 *$ & 30 & 29.1 & $31^{*}$ & 30 & 29.04 & $31.8 *$ & 30.3 & 30.5 \\
\hline$T_{\min }\left({ }^{\circ} \mathrm{C}\right)$ & $16.6^{*}$ & 17.1 & 16.2 & $16.5^{*}$ & 15.6 & 14.8 & $15.6^{*}$ & 15.2 & 15.2 \\
\hline$T_{\text {avg }}\left({ }^{\circ} \mathrm{C}\right)$ & $23.2 *$ & 23.5 & 22.6 & $24.6^{*}$ & 22.7 & 21.8 & $25.1 *$ & 23.01 & 23.1 \\
\hline$T_{\max }-T_{\min }\left({ }^{\circ} \mathrm{C}\right)$ & $13.7^{*}$ & 13 & 12.8 & $12.6^{*}$ & 14.3 & 14.2 & $14.6^{*}$ & 15.1 & 14.8 \\
\hline RHavg (\%) & 52.3 & 50.5 & 56.9 & 47.1 & 54.3 & 58.4 & 46.6 & 52 & 56.5 \\
\hline Rainfall (mm) & $772.6^{*}$ & 909.6 & 786.4 & $808.456 *$ & 786.6 & 741.7 & $421.26^{*}$ & 423.6 & 405.4 \\
\hline
\end{tabular}

All meteorological data (rainfall, temperature) were provided by the Meteorological weather stations placed in Izmir and Manisa. $T_{\max }:$ maximum temperature, $T_{\max }$, maximum temperature; $T_{\min }$, minimum temperature; $T_{\text {avg }}$, average temperature; $\mathrm{RH}_{\text {avg }}$, average relative humidity. All meteorological data were provided by the Meteorological weather stations placed in Izmir and Manisa. $T_{\max }, T_{\min }, T_{\text {avg }}, \mathrm{RH}_{\text {avg }}$ data represents the period between 1st April-30th August. Rainfall data represents whole year. For Menderes 2001-2014 Adnan Menderes station data, for Halilbeyli 1984-97 and 2013-2014 Kemalpasa station data, for Kemaliye 1975-2014 Alasehir station data used for "Long time period" data.

\subsection{Soil analysis}

Soil samples were taken from the center of each sub plot at depths of 30-60 cm at the end of July (Veraison) and after harvest in August 2013 and 2014. Particle size distribution was determined by the Bouyoucos hydrometer method [9] (Bouyoucos, 1962). For microelement analysis (Fe vs. $\mathrm{Zn}$ ), samples were prepared with extraction solution DTPA, diethylene triamine pentaacetic acid and measured using an automatic absorption spectrophotometer by the method of Lindsay vs. Norwell, 1978. Total P was determined by the method of [10]. For the extraction of $\mathrm{K}, \mathrm{Ca}$, and $\mathrm{Mg}, 1 \mathrm{~N}$ Ammonium acetate $(\mathrm{pH}=7)$ used with the method [11]. The extracts were analyzed directly with the automatic absorption spectrophotometer. $\mathrm{pH}$ and $\%$ total salt measured in saturation mud with $\mathrm{pH}$-meter and Wheatstone bridge [12].

\subsection{Standard chemical analysis.}

In the grape must, brix, titratable acidity, $\mathrm{pH}$, reducing sugar were analyzed $[13,14]$.

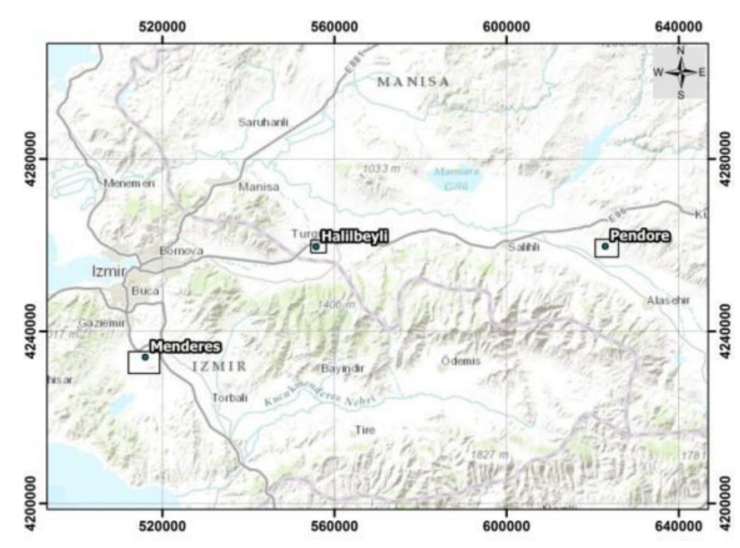

Figure 1. Locations of studied terroirs in Turkey.

\subsection{Aroma compounds analysis}

Extraction: $100 \mathrm{~g}$ grape sample homogenized with a mechanic blender (26,000 rpm), then homogenized sample centrifuged at $0^{\circ} \mathrm{C}, 9000 \mathrm{~g}$. Serum part was transferred into a $500 \mathrm{ml}$ Erlenmeyer flask and cooled to $0^{\circ} \mathrm{C}$ in an ice bath under nitrogen; $40 \mu \mathrm{g}$ of 4-nonanol was added as internal standard because of its high recovery. Dichloromethane (40 $\mathrm{ml})$ was added and the mixture was stirred at $700 \mathrm{rpm}$ for $30 \mathrm{~min}[15,16]$. Then the mixture was centrifuged at $4^{\circ} \mathrm{C}(9000 \mathrm{~g}, 15 \mathrm{~min})$. The organic phase was recovered. The organic extract dried over sodium sulfate and concentrated to a volume of $1 \mathrm{ml}$ with a Vigreux distillation column prior to gas chromatography/mass spectrometry (GC/MS) analysis [2, 15]. Each sample was extracted in triplicate and the concentration of volatiles, as 4-nonanol equivalent, was obtained as the mean of three repetitions.

\subsection{GC-MS-FID conditions}

Gas chromatography and gas chromatography-mass spectrometry analysis of volatiles

The gas chromatography (GC) system consisted of an Agilent 6890 chromatograph equipped with a flame ionization detector (FID) (Wilmington, DE, USA), and an Agilent 5973-Network mass selective detector (MSD). Volatile compounds were separated on DB-Wax $(30 \mathrm{~m}$ length $\times 0.25 \mathrm{~mm}$ i.d. $\times 0.5 \mu \mathrm{m}$ thickness; $\mathrm{J} \& \mathrm{~W}$ Scientific Folsom, CA, USA) column. $3 \mu \mathrm{L}$ sample of extract was injected. Injector and FID detectors were set at $250^{\circ} \mathrm{C}$. The flow rate of carrier gas (helium) was $3.3 \mathrm{~mL} / \mathrm{min}$. The oven temperature of the DB-Wax column was increased from $40^{\circ} \mathrm{C}$ (after $3 \mathrm{~min}$ holding) to $90^{\circ} \mathrm{C}$ at a rate of $2^{\circ} \mathrm{C} /$ min, then at a rate of $3^{\circ} \mathrm{C} / \mathrm{min}$ to $130^{\circ} \mathrm{C}$ and at a rate of $4^{\circ} \mathrm{C} /$ min to $240^{\circ} \mathrm{C}$ with a final hold, at $240^{\circ} \mathrm{C}$ for $12 \mathrm{~min}$. The same oven temperature programs were used for the mass selective detector. The MS (electronic impact ionization) (Agilent 5975B VL MSD) conditions were as follows: ionization energy of $70 \mathrm{eV}$, mass range $\mathrm{m} / \mathrm{z}$ of 29-350 a.m.u., scan rate of $1.0 \mathrm{scan} \mathrm{s}^{-1}$, interface temperature of $250^{\circ} \mathrm{C}$, 
Table 2. Soil parameters of studied terroirs.

\begin{tabular}{|c|c|c|c|}
\hline & Menderes & Halilbeyli & Kemaliye \\
\hline Texture & Loamy & $\begin{array}{l}\text { Sandy } \\
\text { Loam }\end{array}$ & Loamy \\
\hline $\mathrm{P}_{2} \mathrm{O}_{5}(\mathrm{ppm})$ & 2.76 & 2.13 & 1.12 \\
\hline $\mathrm{K}_{2} \mathrm{O}(\mathrm{ppm})$ & 456 & 107 & 125 \\
\hline $\mathrm{Fe}(\mathrm{ppm})$ & 16 & 42 & 4.26 \\
\hline $\mathrm{Zn}(\mathrm{ppm})$ & 0.89 & 1.22 & 0.38 \\
\hline Mn (ppm) & 18 & 29.02 & 16.29 \\
\hline $\mathrm{Cu}(\mathrm{ppm})$ & 4 & 4.05 & 0.31 \\
\hline $\mathrm{MgO}$ (ppm) & 380 & 20 & 161 \\
\hline $\mathrm{Ca}(\mathrm{ppm})$ & 8330 & 980 & 4802 \\
\hline $\mathrm{Na}(\mathrm{ppm})$ & 115 & 37 & 38 \\
\hline $\mathrm{N}(\%)$ & 0.084 & 0.062 & 0.028 \\
\hline OrganicMatter (\%) & 1.81 & 1.29 & 1.08 \\
\hline Salt & 0.059 & 0.016 & 0.016 \\
\hline $\mathrm{pH}$ & 7.61 & 6.12 & 7.82 \\
\hline Lime (\%) & 11.5 & 0.5 & 30.2 \\
\hline
\end{tabular}

and source temperature of $120^{\circ} \mathrm{C}$. The volatile compounds were identified by comparing their retention index and their mass spectra on the DB-Wax column with those of a commercial spectra database (Wiley 6, NBS 75k) and of the instrument's internal library created from the previous laboratory studies. Some of the identifications were confirmed by the injection of the chemical standards into the GC-MS system. Retention indices of the compounds were calculated by using an n-alkane series $[2,15,16]$.

\subsection{Statistical analysis}

The results of terpene compounds were compared by the analysis of variance (ANOVA) and principal component analysis (PCA) was carried out using XLSTAT (2015, Addinsoft, New York, USA). PCA tests were used to determine the significant or differences between regions.

\section{Results and discussion}

\subsection{Soil analysis results}

Soil texture affects moisture availability to the plant due to its moisture retaining capacity. All studied terroirs have similar soil texture, defined as sandy-loamy. Fertility of vineyard soil directly affects vine vigour and metabolism. In turn, it affects the metabolism of the grapes and its wines. As evidenced by the soil analysis results, the most fertile soil belongs to Menderes, followed by Halilbeyli and then Kemaliye due to the nitrogen, phosphor and organic matter levels $(\%)$ which are the most effective factors on vine vigour. Potassium has been associated with grape composition and wine quality, and its presence appears to be linked with acids and $\mathrm{pH}$. Musts, which contain high amounts of $\mathrm{K}$, also tend to have high $\mathrm{pH}$ and high malate, although during vinification malate may drop and $\mathrm{pH}$ may increase even further [21]. Menderes has a greater amount of potassium than Halilbeyli and Kemaliye. Sea water carried by winds brings $\mathrm{Na}, \mathrm{Mg}$ vs. $\mathrm{Ca}$ elements to the innerland, thus it is understandable that Menderes has the highest amounts of these micronutrients, followed by Halilbeyli and Kemaliye according to the proximity to the Mediterranean Sea. According to Lindsay and Novell (1978) $2.5-4.5 \mathrm{mg} / \mathrm{kg} \mathrm{Fe}$ was seen appropriate for vineyards [11]. Halilbeyli has the highest amount of Fe, followed by Menderes and Kemaliye. This also determines the color of the soil and thus, the amount of light reflected from ground surface to the grapes. Additionally, the lighter soil color of Kemaliye (also related to high lime levels) provides more light to grape clusters including the shaded parts of the canopy. Micro elements $\mathrm{Cu}, \mathrm{Zn}, \mathrm{Mn}$, are useful in typical concentrations $(0.1-100 \mathrm{mg} / \mathrm{kg})$, but exhibit toxic effects at higher concentrations [22]. The amount of metal ions such as Fe, and $\mathrm{Cu}$ is higher in the soil of Halilbeyli, followed by Menderes. This can affect the amount of polyphenoloxidase which has copper ions in its structure. There are no salt or $\mathrm{pH}$ problems in the terroirs that were studied. The lime content of the vineyards gives a great difference to the terriors. Kemaliye has a $30 \%$ lime content, followed by Menderes (11.5\%) and Halilbeyli $(0.5 \%)$. In literature it is reported that such soils rich with lime tend to give "high quality wines" with better color, body and aroma intensity with a higher alcohol content due to more sugar from the grapes $[19,20]$.

\subsection{General properties and composition of Muscat of Bornova grapes}

Table 3 shows results for general composition of grapes, and ${ }^{\circ}$ Brix, total acidity, $\mathrm{pH}$, reducing sugar of musts obtained from Bornova Muscat grapes harvested from three terroir in both 2013, 2014. According to the Brix shown in Table 3, grapes from 2013 vintage are riper than grapes from 2014 in all terroirs. The total acidity was lower for the 2013 harvested grapes except in the Halilbeyli. As seen as Table 3, total acidity was lowest in the Halilbeyli in both years. The total acidity of Muscat of Bornova grapes found in the first vintage was between 6.6 and $6.9 \mathrm{~g} / \mathrm{L}$. Kemaliye had the highest $(6.9 \mathrm{~g} / \mathrm{L})$, followed by Halilbeyli $(6.7 \mathrm{~g} / \mathrm{L})$ and Menderes $(6.6 \mathrm{~g} / \mathrm{L})$. Day-night temperature difference is known to affect acidity. Also, higher altitudes tend to be more acidic [21]. On the other hand, in the second vintage, total acidity decreased in Bornova Muscat grapes in all terroirs. Reducing sugar has changed with the year in all terroirs and were lower in 2014 than 2013 vintage. The decrease of total acidity and reducing sugar may have been caused by exposure to high temperatures during ripening of the grapes.

\subsection{Terpene compounds of Muscat of Bornova grapes}

Results for quantification terpene compounds in Bornova Muscat grapes for the three terroirs and both harvests are shown in Table 4. Terpene compounds were identified and quantified in grapes by GC/MSD and GC/FID. 
Table 3. General properties of Muscat of Bornova grapes.

\begin{tabular}{lcccccc}
\hline & \multicolumn{2}{c}{ Menderes } & \multicolumn{2}{c}{ Halilbeyli } & \multicolumn{2}{c}{ Kemaliye } \\
\hline $\begin{array}{l}\text { General properties } \\
\text { of grapes }\end{array}$ & 2013 & 2014 & 2013 & 2014 & 2013 & 2014 \\
$\begin{array}{l}\text { Average bunches of } \\
\text { grape weight }(\mathrm{g})\end{array}$ & $141.77 \pm 25.15$ & $194.85 \pm 60.25$ & $149.68 \pm 33.01$ & $268.42 \pm 36.83$ & $131.53 \pm 43.35$ & $147.9 \pm 38.04$ \\
100 grape weight $(\mathrm{g})$ & $129.05 \pm 3.55$ & $135.25 \pm 3.25$ & $174.61 \pm 2.04$ & $225.60 \pm 2.84$ & $159.65 \pm 0.75$ & $127.63 \pm 4.94$ \\
Brix & $23.0 \pm 0.0$ & $21.6 \pm 0.0$ & $23.0 \pm 0.00$ & $19.6 \pm 0.0$ & $22.3 \pm 0.00$ & $21.4 \pm 0.0$ \\
Total acidity* $(\mathrm{g} / \mathrm{L})$ & $6.6 \pm 0.4$ & $5.6 \pm 0.0$ & $6.8 \pm 0.1$ & $3.24 \pm 0.0$ & $6.9 \pm 0$ & $5.4 \pm 0.04$ \\
Ph & 3.56 & 3.75 & 3.64 & 4.21 & 3.57 & 3.86 \\
$\begin{array}{l}\text { Reducing sugar } \\
(\mathrm{g}(\mathrm{L})\end{array}$ & $220.4 \pm 3$ & $213.52 \pm 1.4$ & $226.0 \pm 0.0$ & $191.68 \pm 5.8$ & $216.2 \pm 0.2$ & $219.76 \pm 1.4$ \\
\hline
\end{tabular}

*As tartaric acid.

Table 4. Terpene compounds of Muscat Bornova grapes from three different terroirs and two different years.

\begin{tabular}{|c|c|c|c|c|c|c|c|}
\hline \multirow[b]{2}{*}{$\begin{array}{l}\text { Terpene compounds } \\
(\mu \mathrm{g} / \mathrm{kg})\end{array}$} & \multicolumn{2}{|c|}{ Menderes } & \multicolumn{2}{|c|}{ Halilbeyli } & \multicolumn{2}{|c|}{ Kemaliye } & \multirow[b]{2}{*}{ Sig. } \\
\hline & 2013 & 2014 & 2013 & 2014 & 2013 & 2014 & \\
\hline Limonen & - & $31.73 \pm 3.2$ & & - & & $24.42 \pm 0.4$ & ns \\
\hline cis-Furan linalooloxide & $34.96 \pm 4.2$ & $35.72 \pm 4.5$ & $21.21 \pm 1.7$ & $13.05 \pm 2.2$ & $15.68 \pm 0.6$ & $28.67 \pm 1.4$ & $*$ \\
\hline trans-Furan linalooloxide & $20.85 \pm 3.2$ & $3.08 \pm 0.3$ & $15.21 \pm 1.4$ & $18.07 \pm 3$ & $22.42 \pm 3$ & $26.69 \pm 1.3$ & $*$ \\
\hline $\begin{array}{l}\text { 2,6-Dimethyl-7-octen-2-ol } \\
\text { linalol }\end{array}$ & - & - & - & - & - & $36.49 \pm 2.9$ & $*$ \\
\hline ho-Trienol & $582.39 \pm 86$ & $522.29 \pm 5.3$ & $269.86 \pm 1.2$ & $363.18 \pm 36.1$ & $456.16 \pm 5.4$ & $838.92 \pm 33.4$ & $*$ \\
\hline$\alpha$-Terpineol & $1.48 \pm 0.4$ & $3.83 \pm 0.3$ & $1.64 \pm 0.4$ & $5.43 \pm 0.5$ & $1.66 \pm 0.1$ & $6.45 \pm 0.5$ & ns \\
\hline \multirow{2}{*}{$\begin{array}{l}\text { 2,6-Octadiene,2,4- } \\
\text { dimethyl }\end{array}$} & $24.83 \pm 3.5$ & $15.65 \pm 1.5$ & $10.46 \pm 1.1$ & $10.31 \pm 0.3$ & $5.91 \pm 0.1$ & $12.91 \pm 0.0$ & $*$ \\
\hline & - & - & $2.23 \pm 0.9$ & - & - & - & $*$ \\
\hline $\begin{array}{l}\text { trans-3,7-dimethyl 2,6- } \\
\text { octadienal }\end{array}$ & $8.79 \pm 1.4$ & $9.65 \pm 1.1$ & $10.29 \pm 2.1$ & $16.27 \pm 1.6$ & $3.23 \pm 0.3$ & $8.42 \pm 0.6$ & $*$ \\
\hline cis -Pyran linalooloxide & $168.98 \pm 28.4$ & $69.03 \pm 7.6$ & $75.5 \pm 11.4$ & $42.06 \pm 10.2$ & $109.2 \pm 2.1$ & $139.38 \pm 0.4$ & $*$ \\
\hline trans-Pyran linalooloxide & $69.13 \pm 0.0$ & $22.94 \pm 3.2$ & $29.72 \pm 1.1$ & $32.77 \pm 6.5$ & $35.65 \pm 1$ & $65.24 \pm 0.1$ & ns \\
\hline Citronellol & $44.66 \pm 3.5$ & $27.47 \pm 2.5$ & $23.56 \pm 0.2$ & $16.53 \pm 2.2$ & $18.21 \pm 0.8$ & $21.08 \pm 0.2$ & $*$ \\
\hline Nerol & $102.32 \pm 9.1$ & $220.35 \pm 10.4$ & $96.9 \pm 1$ & $73.45 \pm 14.4$ & $74.14 \pm 1$ & $166.32 \pm 7.3$ & $*$ \\
\hline Geraniol & $312.42 \pm 48.1$ & $189.47 \pm 11.6$ & $229.33 \pm 2.5$ & $218.16 \pm 0.8$ & $342.37 \pm 0.4$ & $337.44 \pm 0.5$ & $*$ \\
\hline $\begin{array}{l}\text { 2,6-Dimethyl,3,7- } \\
\text { octadiene-2,6-diol }\end{array}$ & $66.29 \pm 3.5$ & $18.83 \pm 1.4$ & $56.3 \pm 1.7$ & $27.74 \pm 1$ & $40.64 \pm 1$ & $79.7 \pm 11.2$ & ns \\
\hline $\begin{array}{l}\text { 3,7-Dimethyl-octa-1,7- } \\
\text { dien,3,6-diol }\end{array}$ & $49.37 \pm 1.9$ & $9.52 \pm 0.8$ & $35.16 \pm 1.6$ & $23.63 \pm 1.5$ & $40.39 \pm 2.5$ & $69.52 \pm 1.6$ & $*$ \\
\hline (E)- $\beta$-farnesene & $50.25 \pm 2.9$ & $200.93 \pm 35$ & $16.02 \pm 0.3$ & $45.41 \pm 13.9$ & $48.4 \pm 0.0$ & $36.6 \pm 4.5$ & $*$ \\
\hline $\begin{array}{l}\text { 3,7-Dimethyl,1,7- } \\
\text { octanediol, }\end{array}$ & - & - & $19.03 \pm 1.3$ & - & $26.03 \pm 1$ & $26.33 \pm 0.3$ & $*$ \\
\hline $\begin{array}{l}\text { 2,6-Dimetil, } \\
\text { 2,7-octadienel-1,6-diol }\end{array}$ & - & - & $18.46 \pm 0.7$ & - & $37.53 \pm 1.6$ & - & $\mathrm{ns}$ \\
\hline Geranic acid & $619.59 \pm 14.5$ & $434.57 \pm 23$ & $408.62 \pm 28.7$ & $399.1 \pm 14.5$ & $422.64 \pm 4.6$ & $703.4 \pm 74.6$ & ns \\
\hline Total & 2156.31 & 1815.06 & 1339.5 & 1305.16 & 1700.26 & 2627.98 & \\
\hline
\end{tabular}

Sig.: Significance at which means differ as shown as analysis of variance, ${ }^{*} p<0.05$ level, ns: not significant. 
Differences were observed in terms of number of terpene compounds depending on terroirs and years. In the first year (2013), grapes from the Menderes had 15 terpene compounds, in the Halilbeyli there were 18 and in the Kemaliye, 17 terpene compounds were identified and quantified. In 2013, the highest concentration of terpene compounds were found in grapes from the Menderes terroir.

In the second year (2014), grapes from Menderes had 16 terpene compounds, in Halilbeyli there were 15 and in Kemaliye, 18 terpene compounds were identified and quantified. The highest concentration of terpene compounds were found in grapes from the Kemaliye in the 2014 vintage. As seen in Table 4, significant differences were found in terpene concentration in Bornova Muscat grapes from the three terroirs. In all three terroirs, linalool, geranic acid and geraniol were the most abundant terpene compounds in Muscat of Bornova grapes.

Muscat of Bornova grapes, Linallol has one of the highest concentrations among all monoterpenes in all three terroirs and in both years 2013, 2014. However, linalool was cons $\equiv$ bly higher than its aroma threshold $(100 \mu \mathrm{g} / \mathrm{L})\left[3, \overline{V_{2}}\right]$ in all samples. In the first vintage (2013), the highest concentration of linallol was found at $582 \mu \mathrm{g} / \mathrm{L}$ in the Menderes; in the second vintage (2014),
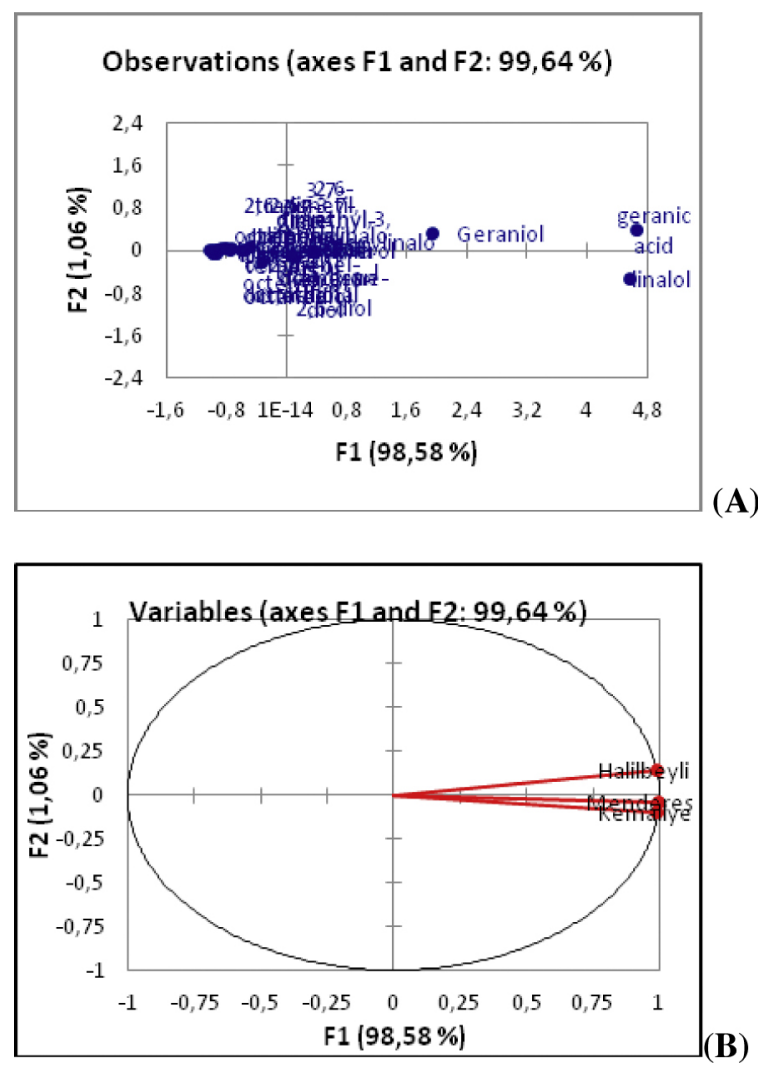

Figure 2. Score plot for the terpene compounds in Bornova. Muscat grapes (A) Projection of the variables on the factor plane $(\mathrm{PC} 1 \times \mathrm{PC} 2)$ considering the aroma compounds quantified. (B) Score plot for the three principal components showing the three terroirs studied. the concentration level was found to be $832 \mu \mathrm{g} / \mathrm{L}$ in the Kemaliye. The lowest linallol concentration was found in Halilbeyli both years, but its concentration level increased in 2014. Linallol concentration changed substantially between years in the Kemaliye. Geraniol concentration exceeded its aroma threshold $(130 \mu \mathrm{g} / \mathrm{L})$ [4] in all three terroirs and in both years 2013, 2014. Among the three terroirs, geraniol was found at the highest concentration in the terroir Menderes in 2013 followed by the Kemaliye and Halilbeyli. The concentration of nerol and $\alpha$-terpineol were lower than their aroma threshold $(400 \mu \mathrm{g} / \mathrm{L})$ [4] in grapes from all three terroir $s$ and in both years of the study. The highest nerol and $\alpha$-terpineol concentrations were found in the terroir Menderes during two years of the study. In Muscat of Bornova grapes, limonen was detected in the second vintage only in the Menderes and Kemaliye whereas it was not detected in the first vintage. Limonen concentration exceeded its aroma threshold $(10 \mu \mathrm{g} / \mathrm{L})$ [5] $\beta$-Farnesene was found at the highest concentrations in the Menderes in both years.

Figure 2 shows PCA performed on terpene compounds of Muscat of Bornova from the three different terroirs. The principle components accounted for $99.64 \%$ of the variance $(98,58$ and $1.06 \%$ respectively). The resulting graphs illustrate relationships among terpene compounds of the grapes which were provided from the three different terroirs. Geraniol and geranic acid have correlation with Halilbeyli terroir. On the other hand linalol has correlation with Kemaliye and Menderes terroirs. Linalool and geraniol are the most important compounds because of their high concentrations normally occurring in Muscat grapes, as well as their low threshold values [4]. A cluster analysis of Bornova Muscat grapes was performed using the level of terpene compounds present in different terroirs and the results were shown in Fig. 3. The height of the branches indicates how similar or dissimilar one region is from the next. The greater the height, the greater the difference among the regions. According to the Dendrogram of the three terroirs of the study, Halilbeyli has a greater difference than the Kemaliye and Menderes.

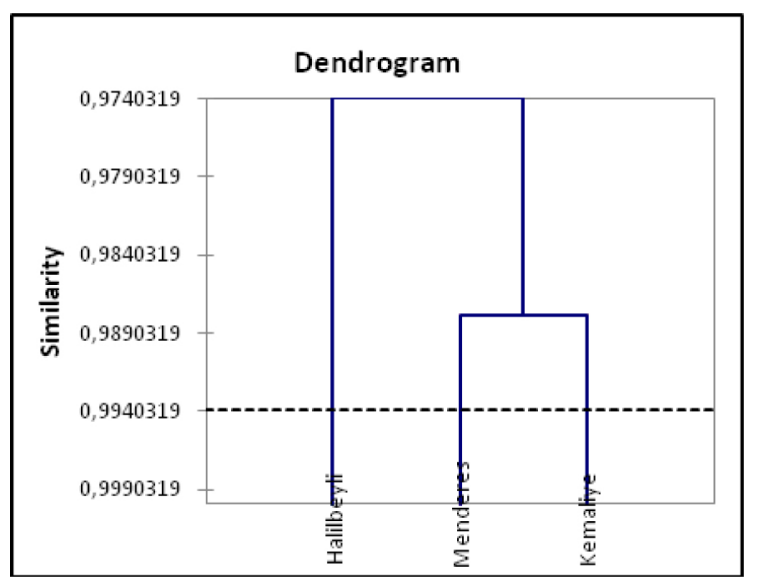

Figure 3. Dendrogram showing the similarity relationship among three terroirs, with terpene compounds in Bornova Muscat grapes. 
Table 5. Monoterpene compounds of Muscat Bornova grapes from three different terroirs and two different years.

\begin{tabular}{lcccccc}
\hline & \multicolumn{2}{c}{ Menderes } & \multicolumn{2}{c}{ Halilbeyli } & \multicolumn{2}{c}{ Kemaliye } \\
\hline $\begin{array}{l}\text { Monoterpene } \\
\text { compounds }(\mu \mathrm{g} / \mathrm{L})\end{array}$ & 2013 & 2014 & 2013 & 2014 & 2013 & 2014 \\
\hline linalol & $582.39 \pm 86$ & $522.29 \pm 5.3$ & $269.86 \pm 1.2$ & $363.18 \pm 36.1$ & $456.16 \pm 5.4$ & $838.92 \pm 33.4$ \\
Citronellol & $44 . .66 \pm 3.5$ & $27.47 \pm 2.5$ & $23.56 \pm 0.2$ & $16 . .53 \pm 2.2$ & $18 . .21 \pm 0.8$ & $21.08 \pm 0.2$ \\
Nerol & $102.32 \pm 9.1$ & $220.35 \pm 10.4$ & $96.9 \pm 1$ & $73.45 \pm 14.4$ & $74.14 \pm 1$ & $166.32 \pm 7.3$ \\
Geraniol & $312.42 \pm 48.1$ & $189.47 \pm 11.6$ & $229.33 \pm 2.5$ & $218.16 \pm 0.8$ & $342.37 \pm 0.4$ & $337.44 \pm 0.5$ \\
Total & 1041.79 & 959.58 & 619.65 & 671.32 & $890 . .88$ & 1363.76 \\
\hline
\end{tabular}

Linalool, citronellol, nerol and geraniol, are the major contributors to berry Muscat flavour when combined, intensity a floral and fruity character similar to that of Muscat aroma [22]. Table 5 shows total monoterpene levels of Bornova Muscat grapes from three terroir. The total monoterpene level of Kemaliye changed distinctly with the year, however it did not change in Menderes and Halilbeyli terroirs.

\section{Conclusion}

The results show that terroir significantly affected Bornova Muscat grapes terpene concentration levels. In 2013 and 2014, totals of 19 and 18 free terpene compounds were identified respectively in Bornova Muscat grapes. The highest concentration of terpene compounds were found in the Menderes in the first vintage, whereas highest concentration of terpene compounds were found in the Kemaliye in the second vintage. The Halilbeyli had the lowest terpene concentration in both years. In all three regions, linalool, geranic acid and geraniol were the most abundant terpene compounds and they were found in higher concentrations than their aroma threshold values indicated in all three terroirs in Muscat of Bornova grapes. However, limonen was detected only in the Menderes and Kemaliye terroirs. Our results show that Halilbeyli had a greater difference than the Kemaliye and Menderes terroirs.

The authors would like to thank The Scientific and Technical Research Council of Turkey (TUBITAK) for financial support of this research (Project No. 112 O 832), MATLI Co Inc., SEVILEN, KAVAKLIDERE Wines Company for providing samples.

\section{References}

[1] C. Van Leeuwen, J.-P.Roby, D. Pernet, B. Bois, Methodology of soil-based zoning for viticultural terroirs. Bulletin de l'O.I.V., 83: 13-29 (2010).

[2] S. Selli, A. Canbas, T. Cabaroglu, H. Erten, Z. Günata, Aroma components of cv. Muscat of Bornova wines and influence of skin contact treatment, Food Chemistry, 94, 319-326 (2003).

[3] P.Ribereau-Gayon, J.N.Boidron, A.Terrier Aroma of muscat grape varieties. J. Agric. Food Chem., Vol. 23, No. 6 (1975).

[4] J. Marais, Terpenes in aroma of grapes and wines: A Review. J. Afr. J. Enol. Vitic., Vol. 4, No. 2 (1983).

[5] J. Fenoll, A. Manso, P. Hellin, L. Ruiz, P. Flores, Changes in the aromatic composition of the Vitis vinifera grape Muscat Hamburg during ripening. Food Chem., 114, 420-428 (2009).

[6] N. Mateus, S. Proença, P. Ribeiro, J. M. Machado ve V.D. Freitas, Grape and wine phenolic composition of red Vitis vinifera varieties concerning vineyard altitude. Ciencia y Tecnologia Alimentaria, 3, Issue 2. (2001).

[7] A. G. Reynolds, and A. P. Naylor. Pinot noir and Riesling grape vines respond to water stress duration and soil water-holding capacity. Hort Sci. 29: 1505-1510 (1994).

[8] G. Mazza, L. Fukumoto, P. Delaquis, B. Girard, and B. Ewert. Anthocyanins, phenolics, and color of cabernet franc, merlot, and pinot noir wines from British Columbia. J. Agric. Food Chem. 47: 4009-4017 (1999).

[9] S. E. Spayd, J. M. Tarara, D. L. Mee, and J. C. Ferguson. Separation of sunlight and temperature effects on the composition of Vitis vinifera $\mathrm{cv}$. Merlot berries. Am. J. Enol. Vitic. 53: 171-182 (2002).

[10] S. R. Olsen, and L. E. Sommers, Phosphorus in Methods of Soil Analysis Part 2. Chemical and Microbiolgial Properties. Agronomy Monograph No 9. 8 Ed. Page, A. L. Asa-Sssa. Madison, USA (1982).

[11] B. Kacar, Bitki Besleme, Ankara Üniversitesi Ziraat Fakültesi Ders Yayınları, Ankara (1984).

[12] E. Schlichting, H.P. Blume, Bodenkundliches Praktikum : eine Einfuehrung in pedologisches Arbeiten fuer Oekologen, insbesondere Land- und Forstwirte, und fuer Geowissenschaftler. Methods of SoilAnalysis (in German), 209 pp., Parey, Hamburg, Ger., (1966).

[13] OIV, International Organisation of Vine and Wine, Compendium of International Methods of Wine and Must Analysis. Edition 2012, Volume 2 (2012).

[14] VC.S. Ough, M.A. Amerine, Methods for Analysis os Musts and Wines, John Willey and Sons, New York, p.377 (1988).

[15] R. Schneider, R. Baurmes, C.L. Bayonove, A. Razungles, Volatile components involved in the aroma of sweet fortified wines (vins doux naturels) from Grenache noir. Journal of Agriculture Food and Chemistry. 46, 3230-3237 (1998).

[16] R. Schneider, A. Razungles, C. Augier, R. Baumes. Monoterpenic and norisoprenoidic glycoconjugates of Vitis vinifera L. Cv. Melon B. as precursosrs ofodorants in Muscdet wines. Journal Cahromatography A. 936, 145-152 (2001) 
[17] D. I. Jackson, P. B. Lombard. Environmental and Management Practices Affecting Grape Composition and Wine Quality-A Review. Am. J. Enol. Vitic., Vol. 44, No. 4. 1993

[18] W.L. Lindsay, W.A. Norwell, Development of DTPA soil test for zinc, iron, manganese and copper. Soil Sci. Amer. Jour., 42(3), 421-428 (1978).

[19] R. White, L. Balachandra, R. Edıs, D. Chen, The Soil Component of Terroir, J. Int. Sci. Vigne Vin, $\mathbf{4 1}, \mathrm{n}^{\circ} 1$, 9-18 (2007).
[20] E.A.C. Constantini, P. Bucell1, S. Priori. VIII International Terroir Congress June 14th-18th, Soave-Italy (2010).

[21] P. Ribéreau-Gayon, Y. Glories, A. Maujean, D. Dubourdieau, Handbook of Enology, Volume 2: The Chemistry of Wine and Stabilization and Treatments. John Wiley and Sons Ltd., England (2000).

[22] J.J.Mateo, M. Jimenez, Monoterpenesin grapes, juice and wines: A Review. Journal of Chromatography A, 881, 557-567 (2000). 